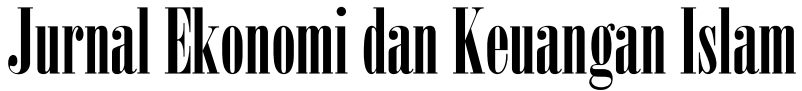

Available at https://journal.uii.ac.id/jeki

\section{The antecedents of Muslim customers' behavioral intention towards Islamic mobile payment}

\author{
Exval Mahendra Saputro, Sri Rahayu Hijrah Hati \\ Master of Management, Faculty of Economics and Business, Universitas Indonesia, Jakarta, Indonesia
}

\section{Article History}

Received : 16 June 2021

Revised : 28 June 2021

Accepted : 29 June 2021

Published : 1 July 2021

Keywords:

Islamic mobile payment; Muslim customers; Behavioral intention

DOI:

https://doi.org/10.20885/JEKI.vol7.is s2.art2

JEL Clasification:

G20, M30, M31

Corresponding author:

exvalmahendra@gmail.com

Author's email:

sri.rahayu72@ui.ac.id

Paper type:

Research paper

Cite this article:

Saputro, E. M., \& Hati, S. R. H. (2021). The antecedents of Muslim customers' behavioral intention towards Islamic mobile payment. Jurnal Ekonomi dan Keuangan Islam, 7(2), 123-138. https://doi.org/10.20885/JEKI.vol7.is s2.art2

\begin{abstract}
Purpose - The aim of the study is to identify the antecedents of the Indonesian Muslim customers' intention to use Islamic mobile payments.
\end{abstract}

Methodology - The data were collected from 437 respondents, i.e., 216 potential users and 221 actual users of Islamic mobile payments. The data were analyzed using a partial least squares structural equation model (PLS-SEM).

Findings - The study shows that performance expectancy, perceived religiosity obligation, compatibility, and perceived trust had positive effects on the behavioral intention of Muslim customers. For multigroup analysis, perceived religiosity obligation and compatibility have a significant effect on actual and potential users. Perceived trust significantly influences actual users' behavioral intentions, whereas social influence only significantly affects potential users.

Originality - The study was conducted on Islamic mobile payment using actual users and potential users as respondents. The study will contribute to the development of theories on the adoption of technology and Muslim consumers.

\section{Introduction}

The development of information technology affects various aspects of customers' lives. Since the inception of mobile phones, various services and applications have been developed to increase customers' productivity (Abrahão et al., 2016; Alalwan, 2018). The development of mobile technology also has impacted financial transactions, such as mobile payments (Choi et al., 2020; Liébana-Cabanillas et al., 2017; Phonthanukitithaworn et al., 2016).

Mobile payments refer to any payments that use a mobile device to initiate, authorize, and confirm payment transactions (Au \& Kauffman, 2008; Lin et al., 2020). Mobile payments do not merely move transactions using mobile devices; they also increase convenience in transactions, especially online payments (Iman, 2018; Lin et al., 2020). Mobile payments are an alternative payment method for transactions for goods, services, and bills (Lin et al., 2020). Purchases of goods also can be made at point-of-sale (POS), such as vending machines or at machines where tickets 
are purchased (Iman, 2018). Mobile payment and security also offer various conveniences for consumers, such as reducing the use of cash, which can be used anytime and anywhere, one-click payment, history of small expenses to discounts, and provision of cashback (Sobti, 2019).

Since Indonesia has the largest Muslim population in the world, the Islamic financial services development, including Islamic mobile payments, has a high potential to grow rapidly there (Prayoga, 2020; Suhartadi, 2020). The National Sharia Board-Indonesian Ulama Council (DSNMUI) has issued a fatwa that serves as the basis for provider companies to adjust their services to use Islamic economic principles (MUI, 2018). In 2020, the local Islamic bank launched the first Islamic mobile payment service (KNEKS, 2020; Linkaja, 2020). According to the National Committee for Islamic Economy and Finance (KNEKS), Islamic digital payments need to keep up with technological developments in the financial services industry (KNEKS, 2019). Islamic mobile payment penetration in Indonesia is considered low. As an integrated e-wallet service created through a merger of the e-wallets of Indonesian telco Telkomsel and lenders Bank Mandiri, BRI, and BNI, LinkAja had more than 61 million users as of December 2020. In contrast, up to March 2021, there were only 2.5 million users of LinkAja Syariah (Banjarnahor, 2021; Jatmiko, 2021). Bank Syariah Mandiri had targeted Quick Response Code Indonesian Standard (QRIS) transactions to reach 300,000 transactions with a volume of IDR 20 billion, while the volume of transactions that occur at Mandiri Syariah Mobile in 2020 to reach IDR 50.26 trillion (Walfajri, 2020; Liputan6.com, 2021). The figure shows that most Indonesian customers have lower preferences for the Islamic mobile payment services than they have for conventional mobile payment services.

The low adoption of the Islamic mobile payment service has raised the question concerning why this phenomenon occurred in a large Muslim country, such as Indonesia. There are many theories that explain the adoption of technology by customers, e.g., the Technology Acceptance Model (TAM) (Davis, 1989; Davis et al., 1989), Innovation Diffusion Theory (IDT) (Rogers, 2003), and the Unified Theory of Acceptance and Use of Technology (UTAUT) (Venkatesh et al., 2003, 2012). Also, previous research has added other factors to the theories, including perceived risk, perceived cost (Abrahão et al., 2016; Phonthanukitithaworn et al., 2016; Sobti, 2019), perceived trust (Jamshidi \& Hussin, 2016; Patil et al., 2020; Phonthanukitithaworn et al., 2016), and also religiosity (Amin et al., 2011; Jamshidi \& Hussin, 2016; Suhartanto et al., 2019). Research on determinants of the behavioral intention of mobile payments has been conducted in several countries, including Thailand (Phonthanukitithaworn et al., 2016), Brazil (Abrahão et al., 2016; De Luna et al., 2017), Malaysia (Moorthy et al., 2020; Tan \& Leby Lau, 2016), India (Patil et al., 2020; Sobti, 2019), and Indonesia (Handarkho et al., 2021; Putri et al., 2020; Ramdhani et al., 2020). However, those studies did not discuss the behavioral intentions of the customers in the context of Islamic mobile payment. Since the Islamic mobile payment services are relatively new, the study is expected to provide empirical evidence on the factors that affect the behavioral intentions of potential users and actual users in using Islamic mobile payments.

\section{Literature Review}

\section{Mobile Payment}

Mobile payment is a payment method that provides convenience in financial transactions (Mouakket, 2020). Mobile payment is considered a technology development that can change consumer financial transactions and service providers (Molina-Castillo et al., 2020). Mobile payment refers to a mobile device payment transaction (Choi et al., 2020; Sobti, 2019). Mobile devices are only a medium where financial transactions can be initiated, processed, and confirmed (Iman, 2018).

Mobile payments were classified into two criteria, i.e., 1) proximity, which is based on the consumer's physical location and 2) a business model that is based on the differences in the relationships between consumers and companies (De Luna et al., 2019; Innopay et al., 2013). Mobile payments can be made using various technologies, such as Near Field Communication (NFC), One-Time Password (OTP), QR Code, and other technologies (De Luna et al., 2017, 2019). 
Mobile payments are considered to be capable of turning mobile devices into digital wallets, replacing cash, credit cards, savings accounts, and other payment instruments (Lin et al., 2020). Mobile payment is defined as the use of mobile devices to make payment transactions where funds are transferred from the buyer to the seller either directly or by intermediaries (Mallat, 2007). Mobile payment is a general transaction service that banks or fintech companies or IT companies connected to banks (Iman, 2018; Kang, 2018). Mobile payments can be used for various payments, including mobile banking and mobile commerce (Iman, 2018; Sobti, 2019).

Islamic mobile payment is a development of conventional mobile payment services that applies Islamic principles to fund transactions. Service providers will apply Islamic principles developed based on a fatwa from the National Sharia Board - Indonesian Ulema Council (DSNMUI). Islamic banking will be involved either as a service provider connected to mobile banking or a partner for managing the collection of funds (Linkaja, 2020).

\section{Hypotheses Development}

One of the theories that discuss the acceptance model is the Unified Theory of Acceptance and Use of Technology (UTAUT) (Venkatesh et al., 2003). Four factors, among others, influence a person's behavior to use technology, i.e., performance expectancy (PE), effort expectancy (EE), social influence (SI), and facilitating conditions (FC) (Venkatesh et al., 2003). Performance expectancy refers to the expectation of someone who believes the use of the system will help achieve job performance (Abrahão et al., 2016; Venkatesh et al., 2003). This definition is similar to perceived usefulness, namely the individual's belief that job performance will increase the use of a particular system (Davis, 1989; Liu et al., 2019; Tan \& Leby Lau, 2016). Individuals' perceptions that using mobile payments will improve payment performance affect their intentions to use such payments (Liu et al., 2019; Oliveira et al., 2016). Thus:

$\mathrm{H}_{1}$ : Performance expectancy $(\mathrm{PE})$ has a significant positive effect on the behavioral intention (BI) to use Islamic mobile payments.

Effort expectancy is an individual's expectation regarding the ease of use of the system (Abrahão et al., 2016; Venkatesh et al., 2003). This definition is similar to perceived ease of use, namely, the individual believes that using a system/technology does not require a lot of effort (Davis, 1989; Liu et al., 2019; Tan \& Leby Lau, 2016). When users feel that mobile payments are easy to use, they have high expectations for the performance they want (Oliveira et al., 2016; Venkatesh et al., 2003). Individuals may judge a system as applicable but still may be reluctant to use it if it is difficult to use. Perceived ease of use is an antecedent of perceived usefulness (Davis, 1989). Previous research has found that effort expectancy also affects performance expectancy (Liu et al., 2019; Tan \& Leby Lau, 2016). Therefore:

$\mathrm{H}_{2 a}$ : Effort expectancy (EE) has a significant positive effect on behavioral intention (BI) to use Islamic mobile payments.

$\mathrm{H}_{2 b}$ : Effort expectancy (EE) has a significant positive effect on performance expectancy (PE).

Social influence is how someone feels that another influential person believes that he or she must use a new system (Abrahão et al., 2016; Venkatesh et al., 2003). Social influence is a significant predictor of behavioral intention (Patil et al., 2020). People also tend to respect other people's opinions and ideas (Tan \& Leby Lau, 2016). If the opinion of the environment is positive, it will encourage the use of the system (Oliveira et al., 2016; Venkatesh et al., 2003). Thus:

$\mathrm{H}_{3}$ : Social influence has a significant positive effect on behavioral intention to use Islamic mobile payments.

Religiosity is a person's ability to commit to religious rules by adhering to what can and should not be done, values, practices in their daily life (Johan et al., 2020; Suhartanto et al., 2019). Religious obligation is related to the role of religion in influencing one's choices and activities (Amin et al., 2011; Jamshidi \& Hussin, 2016). Religious obligation involves the perception of complying 
with the underlying Islamic principles (Amin et al., 2011; Jaffar \& Musa, 2014). An Islamic financial institution must adhere to Islamic principles, values, and goals when offering its products (Amin et al., 2011). Such compliance can influence a person's decision to research and use the product. The more obedient to Islamic principles a person is, the more likely that person is to use the product (Amin et al., 2011; Jamshidi \& Hussin, 2016). Religiosity affects consumers' behaviors as well as their individual perceptions of the usefulness or performance of a product Jamshidi \& Hussin, 2016; Tang \& Li, 2015). Previous research has shown that religiosity has a positive effect on both behavioral intentions and the perceived usefulness or performance of the product (Jamshidi \& Hussin, 2016; Suhartanto et al., 2019). Therefore:

$\mathrm{H}_{4 a}$ : Perceived religiosity obligation (PRO) has a significant positive effect on behavioral intention (BI) to use Islamic mobile payments.

$\mathrm{H}_{4 \mathrm{~b}}$ : Perceived religiosity obligation (PRO) has a significant positive effect on performance expectancy (PE).

Compatibility refers to how individuals judge a system according to their needs, habits, values, and beliefs (Phonthanukitithaworn et al., 2016; Rogers, 2003). A high degree of conformity will lead to the expected use of the system (Liu et al., 2019; Rogers, 2003). Consumers may accept products or services that are offered if they quickly change their usage behavior (Lin et al., 2020; Rogers, 2003). Compatibility is related to the suitability between individual work styles and the use of a system (Venkatesh et al., 2003). Previous research has shown compatibility is an essential aspect of the adoption of innovation, and it influences individuals' intentions to use the system (Lin et al., 2020; Phonthanukitithaworn et al., 2016). Thus:

$\mathrm{H}_{5}$ : Compatibility (COM) has a significant positive effect on behavioral intention (BI) to use Islamic mobile payments.

Perceived trust is about how individuals feel concerning whether other parties will do particular actions even though they cannot supervise or control those other parties (Mayer et al., 1995; Phonthanukitithaworn et al., 2016). Based on the perspective of IDT theory, consumers' perceived trust in innovations is essential at the pre-adoption stage (Liu et al., 2019; Phonthanukitithaworn et al., 2016). Trust can refer to the consumers' confidence regarding the honesty of the company in its treatment of consumers, and it means that the company's employees will not be opportunistic (Gefen et al., 2003; Zhou, 2011). Trust is an essential factor in electronic banking/financial transactions (Jamshidi \& Hussin, 2016; Patil et al., 2020). In a trusting relationship, the other party will believe that the trusted party will fulfill her or his commitments irrespective of the vulnerability and dependency that may exist (Gefen et al., 2003). Therefore:

$\mathrm{H}_{6}$ : Perceived trust (PT) has a significant positive effect on behavioral intention (BI) to use Islamic mobile payments.

Perceived risk is how individuals believe the use of the system will have negative consequences that may occur (Abrahão et al., 2016; Phonthanukitithaworn et al., 2016; Zhang et al., 2012). Perceived risk is a construct that explains the feeling of uncertainty in consumers related to negative consequences due to new systems and technologies (Liu et al., 2019; Pavlou, 2003; Phonthanukitithaworn et al., 2016). Individuals are less motivated to use a new system if their use has a greater risk than the existing system (Schierz et al., 2010). Perceived risk becomes an essential factor at the pre-adoption stage if a person does not have experience and is aware of the consequences that will be faced (Phonthanukitithaworn et al., 2016). Thus:

$\mathrm{H}_{7}$ : Perceived risk (PR) has a significant negative effect on behavioral intention (BI) to use Islamic mobile payments.

Additional costs will be incurred to adopt new systems and technologies (Phonthanukitithaworn et al., 2016). Perceived cost is how individuals believe the use of the system will result in additional costs, time, and effort (Abrahão et al., 2016; Luarn \& Lin, 2005). Annoying 
experiences, such as slow connections, poor quality, and errors, that occur to online users are among the things that result in additional costs and Efforts (Wu \& Wang, 2005). Other previous studies have shown that cost is a barrier to the use of new technology in cell phone services (Phonthanukitithaworn et al., 2016; Sobti, 2019) Therefore:

$\mathrm{H}_{8}$ : Perceived cost (PC) has a significant negative effect on behavioral intention (BI) to use Islamic mobile payments.

Experience is one of the moderating variables in UTAUT $\leftarrow$ Has that been defined anyahere? theory, along with age, gender, and voluntary use (Venkatesh et al., 2003). Users who already have experience with mobile financial transactions will be more accepting of the mobile payment services that are offered (Venkatesh et al., 2003). Previous research also has shown that different factors affect the use of mobile payments between actual users and potential users (Liébana-Cabanillas et al., 2014; Phonthanukitithaworn et al., 2016). Thus:

$\mathrm{H}_{9}$ : There are significant differences in perceptions and behavioral intention between actual users and potential users.

Based on the above literature review, the following framework was developed based on the theory of consumer acceptance, perceived risk, perceived cost, perceived trust, and perceived religiosity obligation on behavioral intention concerning Islamic mobile payments in Indonesia.

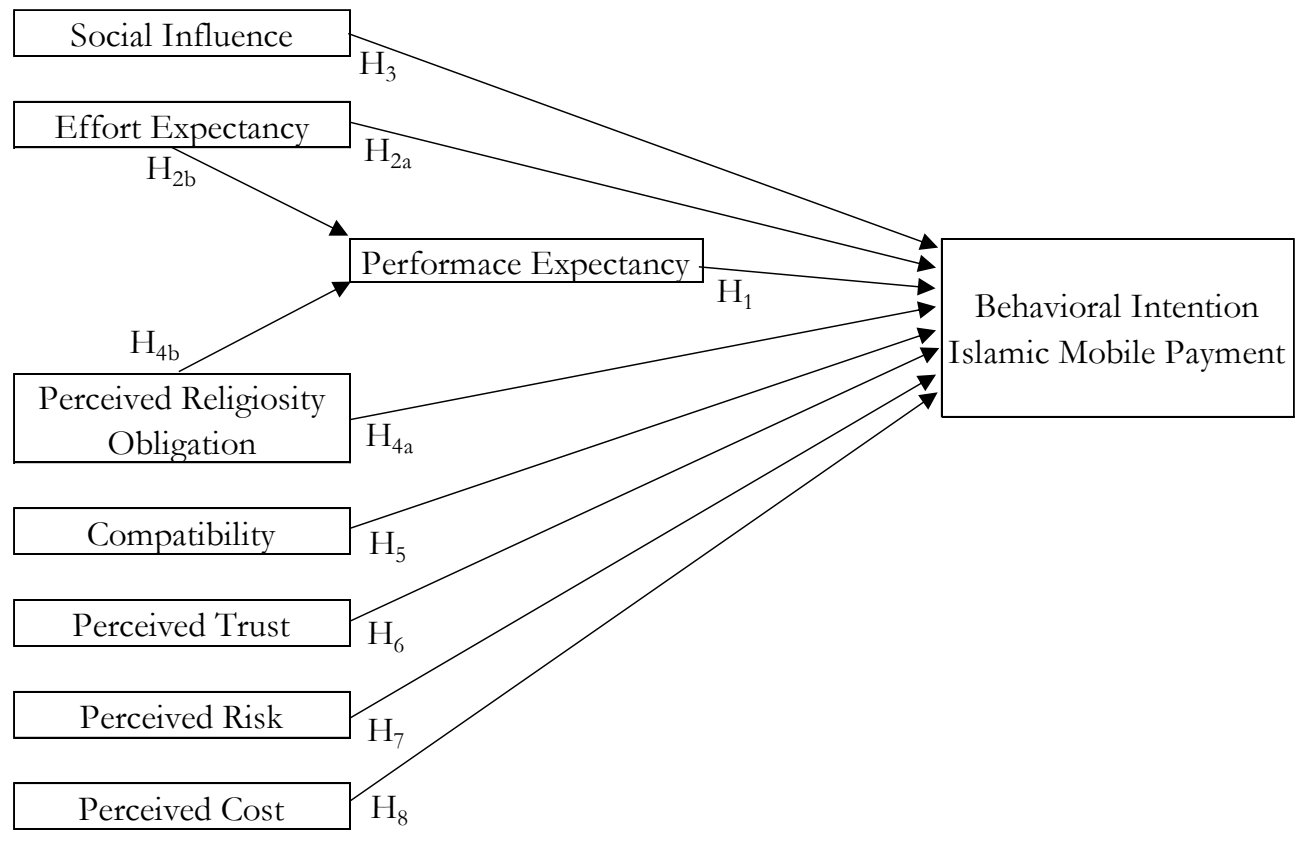

Figure 1. Conceptual Model (Abrahão et al., 2016; Jamshidi \& Hussin, 2016; Phonthanukitithaworn et al., 2016; Tan \& Leby Lau, 2016)

\section{Research Methods}

The research applied a conclusive-descriptive study that attempted to explain certain conditions by testing the hypotheses developed in the research model to determine the factors that affect the behavioral intention associated with Islamic mobile payments. The study used primary data obtained through online surveys. As shown in Appendix 1, the questionnaire consisted of 35 questions using a seven-point Likert scale. A seven-point Likert scale was used because it has a much stronger correlation and a more accurate measurement than a five-point Likert scale (Finstad, 2010; Lewis, 1993). In addition, the previous studies that used a similar questionnaire also used a similar number of scales (Abrahão et al., 2016; Finstad, 2010; Phonthanukitithaworn et al., 2016).

In this study, we used a non-probability sampling method with convenience sampling. Respondents were screened with questions about their knowledge of Islamic mobile payments, 
including known brands. Questions regarding the use of Islamic mobile payments were used as the basis for the formation of the actual user group and the potential user group. A partial least-squares structural equation model (PLS-SEM) was used to analyze the measurements via SmartPLS. MultiGroup Analysis was used to test the differences between the behavioral intentions of actual users and potential users.

A total of 502 respondents completed the questionnaire. After data cleaning and by screening respondents who were Muslim and knew about Islamic mobile payment services, there were 437 questionnaires that were eligible to be used to test the model. The number of samples met the minimum requirement of the structural equation modeling, which has been suggested to be five to ten times the number of indicators (Hair et al., 2011).

\section{Results and Discussion}

\section{Results}

The respondents' profiles are shown in Table 1 . The majority of the respondents were females $(235 ; 53.78 \%)$, and their age range was 26 to 35 years $(202 ; 46.22 \%)$. Their monthly incomes totalled 7.5 million IDR, and they had saving accounts at both conventional and Sharia banks $(214 ; 48$, $97 \%$ ). Based on usage $\leftarrow$ Usage of what? Please clarify. experience, there were 221 actual users and 216 potential users.

Tabel 1. Respondents' profile

\begin{tabular}{|c|c|c|c|}
\hline Profile & Descriptions & Frequency & $\%$ \\
\hline \multirow{3}{*}{ Gender } & Male & 202 & $46.22 \%$ \\
\hline & Female & 235 & $53.78 \%$ \\
\hline & $18-25$ years old & 130 & $29.75 \%$ \\
\hline \multirow{3}{*}{ Age } & $26-35$ years old & 202 & $46.22 \%$ \\
\hline & $36-45$ years old & 67 & $15.33 \%$ \\
\hline & $=>46$ years old & 38 & $8.70 \%$ \\
\hline \multirow{5}{*}{ Monthly income } & $<=$ IDR $7,500,000$ & 233 & $53.32 \%$ \\
\hline & IDR 7,500,001 - 15,000,000 & 159 & $36.38 \%$ \\
\hline & IDR $15,000,001-22,500,000$ & 33 & $7.55 \%$ \\
\hline & IDR 22,500,001 - 30,000,000 & 6 & $1.37 \%$ \\
\hline & $>=$ IDR 30,000,000 & 6 & $1.37 \%$ \\
\hline \multirow{3}{*}{$\begin{array}{l}\text { Saving account } \\
\text { ownership }\end{array}$} & Only on conventional bank & 122 & $27.92 \%$ \\
\hline & Only on Islamic bank & 101 & $23.11 \%$ \\
\hline & Both (conventional and Islamic bank) & 214 & $48.97 \%$ \\
\hline \multirow{2}{*}{ Usage } & Actual user & 221 & $50.57 \%$ \\
\hline & Potential user & 216 & $49.43 \%$ \\
\hline
\end{tabular}

Based on Table 2, the average variance extracted (AVE) value of all variables had a value greater than 0.500 . This condition indicated that the indicators are valid to measure the variables. The results show that the values of Composite reliability and Cronbach's alpha were greater than 0.7 for each construct, which shows that all variables are reliable for analyzing the measurement model.

Tabel 2. Measurement model test

\begin{tabular}{lccc}
\hline \multicolumn{1}{c}{ Constructs } & AVE & CR & Cronbach Alpha \\
\hline Performance Expectancy & 0.832 & 0.952 & 0.933 \\
Effort Expectancy & 0.804 & 0.943 & 0.919 \\
Social Influence & 0.752 & 0.923 & 0.887 \\
Perceived Religiosity Obligation & 0.807 & 0.944 & 0.92 \\
Compatibility & 0.882 & 0.957 & 0.933 \\
Perceived Trust & 0.848 & 0.965 & 0.955 \\
Perceived Risk & 0.859 & 0.961 & 0.946 \\
Perceived Cost & 0.605 & 0.853 & 0.87 \\
Behavioral Intention & 0.935 & 0.977 & 0.965 \\
\hline
\end{tabular}


Based on the Fornell-Lacker values in Table 3, all variables were valid and different from each other, so they can provide different impacts on the research model.

Tabel 3. Fornell-Lacker test

\begin{tabular}{crrrrrrrrr}
\hline Fornell-Lacker & COM & \multicolumn{1}{c}{ EE } & \multicolumn{1}{c}{ INT } & PC & PE & PR & PT & RO & SI \\
\hline COM & 0.941 & & & & & & & & \\
EE & 0.706 & 0.895 & & & & & & & \\
INT & 0.698 & 0.559 & 0.968 & & & & & & \\
PC & -0.154 & -0.265 & -0.119 & 0.806 & & & & & \\
PE & 0.758 & 0.744 & 0.646 & -0.200 & 0.911 & & & & \\
PR & -0.159 & -0.271 & -0.193 & 0.684 & -0.230 & 0.919 & & & \\
PT & 0.531 & 0.604 & 0.594 & -0.225 & 0.580 & -0.390 & 0.917 & & \\
RO & 0.471 & 0.543 & 0.557 & -0.240 & 0.523 & -0.365 & 0.703 & 0.897 & \\
SI & 0.751 & 0.668 & 0.636 & -0.083 & 0.714 & -0.188 & 0.569 & 0.528 & 0.869 \\
\hline
\end{tabular}

The results of hypotesting are provided in Table 4. Based on the analysis, performance expectancy has a significant positive influence on behavioral intention, with a t-value of 2.342 . Thus, $\mathrm{H}_{1}$ is supported. Effort expectancy also was found to significantly influence behavioral intention (t-value: 1.766) and performance expectancy (t-value: 12.146). Therefore, $\mathrm{H}_{2 \mathrm{~b}}$ and $\mathrm{H}_{2 \mathrm{~b}}$ are supported. Social influence also has a significant positive influence on behavioral intention, with a t-value of 1,740 . Thus $\mathrm{H}_{3}$ is supported. Perceived religiosity obligation significantly influences behavioral intention ( $\mathrm{t}$-value: 2.969 ) and performance expectancy (t-value: 3.914). Therefore, both $\mathrm{H}_{4 \mathrm{a}}$ and $\mathrm{H}_{4 \mathrm{~b}}$ are supported. Both compatibility (t-value: 6.101) and perceived trust (t-value: 2.980) significantly and positively influence behavioral intention. Therefore, $\mathrm{H}_{5}$ and $\mathrm{H}_{6}$ also were supported. In contrast, perceived risk (t-value: 0.262;) and perceived cost (t-value: 0.735 ) do not have a significant negative influence on behavioral intention. Therefore, $\mathrm{H}_{7}$ and $\mathrm{H}_{8}$ were not supported.

Tabel 4. Hypothesis testing

\begin{tabular}{clcc}
\hline \multicolumn{1}{c}{ Hypothesis } & Path & Path Coefficients & t-value \\
\hline $\mathrm{H}_{1}$ & Performance Expectancy $\rightarrow$ Behavioral Intention & 0.160 & $2.342^{*}$ \\
$\mathrm{H}_{2 \mathrm{a}}$ & Effort Expectancy $\rightarrow$ Behavioral Intention & -0.101 & $1.766^{*}$ \\
$\mathrm{H}_{2 \mathrm{~b}}$ & Effort Expectancy $\rightarrow$ Performance Expectancy & 0.653 & $12.146^{*}$ \\
$\mathrm{H}_{3}$ & Social Influence $\rightarrow$ Behavioral Intention & 0.095 & $1.740^{*}$ \\
$\mathrm{H}_{4 \mathrm{a}}$ & Perceived Religiosity Obligation $\rightarrow$ Behavioral Intention & 0.167 & $2.969^{*}$ \\
$\mathrm{H}_{4 \mathrm{~b}}$ & Perceived Religiosity Obligation $\rightarrow$ Performance Expectancy & 0.168 & $3.914^{*}$ \\
$\mathrm{H}_{5}$ & Compatibility $\rightarrow$ Behavioral Intention & 0.405 & $6.101^{*}$ \\
$\mathrm{H}_{6}$ & Perceived Trust $\rightarrow$ Behavioral Intention & 0.188 & $2.980^{*}$ \\
$\mathrm{H}_{7}$ & Perceived Risk $\rightarrow$ Behavioral Intention & 0.011 & 0.262 \\
$\mathrm{H}_{8}$ & Perceived Cost $\rightarrow$ Behavioral Intention & 0.032 & 0.735 \\
\hline
\end{tabular}

Note: ${ }^{*}$ significance at $p<0.05$

Multi-Group Analysis was conducted by dividing the respondents into an actual users' group ( $\mathrm{n}=221$ respondents) and a potential users' group ( $\mathrm{n}=216$ respondents) (See Table 5.) In the actual users' group, based on the t-value of 0.228 , performance expectancy does not significantly influence behavioral intention. Thus $\mathrm{H}_{1}$ is not supported. Effort expectancy does not significantly influence behavioral intention ( $\mathrm{t}$-value: 0.573), but it significantly influences performance expectancy (t-value: 25.064). Therefore, $\mathrm{H}_{2 \mathrm{a}}$ is not supported, but $\mathrm{H}_{2 b}$ is supported. Social influence, with a t-value of 0.484 , does not have a significant influence. Thus, $\mathrm{H}_{3}$ was not supported. Perceived religiosity obligation significantly influences behavioral intention ( $t$-value: 2.969), but it does not significantly influence performance expectancy (t-value: 0.912). Therefore, $\mathrm{H}_{4 \mathrm{a}}$ is supported and $\mathrm{H}_{4 \mathrm{~b}}$ is not supported. Both compatibilities with a t-value of 4.086 and perceived trust with a t-value of 3.179 have significant positive influences on behavioral intention. 
Therefore, $\mathrm{H}_{5}$ and $\mathrm{H}_{6}$ are supported. The perceived risk, with a t-value of 0.010 , and the perceived cost, with a t-value of 0.020 , do not have a significant negative influence on behavioral intention. Therefore, $\mathrm{H}_{7}$ and $\mathrm{H}_{8}$ are not supported.

In the potential users' group, performance expectancy, with a t-value of 1.480, does not significantly influence behavioral intention. Thus, $\mathrm{H}_{1}$ is not supported. Effort expectancy significantly affects behavioral intention (t-value: 2.584 ), but the path coefficients have negative values. Thus, $\mathrm{H}_{2 a}$ is not supported. Effort expectancy has a significant positive effect on performance expectancy (t-value: 5.940 ). Thus, $\mathrm{H}_{2 \mathrm{~b}}$ is supported. Social influence significantly and positively influences behavioral intention with a $\mathrm{t}$-value of 2.851 . Thus, $\mathrm{H}_{3}$ is supported. Perceived religiosity obligation positively affects behavioral intention (t-value: 2.183 ) and performance expectancy (t-value: 4.028). Therefore, both $\mathrm{H}_{4 a}$ and $\mathrm{H}_{4 \mathrm{~b}}$ are supported. Compatibility, with a $\mathrm{t}-$ value of 4,086 , has a significant positive influence on behavioral intention. Thus, $\mathrm{H}_{5}$ is supported. Perceived trust has a significant positive influence on behavioral intention ( $\mathrm{t}$-value: 1.735). Thus, $\mathrm{H}_{6}$ is supported. Neither perceived risk, with a t-value of 1.195 , nor perceived cost, with a $\mathrm{t}$-value of 0.526 , has a significant negative influence on behavioral intention. Therefore, $\mathrm{H}_{7}$ and $\mathrm{H}_{8}$ are not supported.

Tabel 5. Multi-group analysis

\begin{tabular}{|c|c|c|c|c|c|c|}
\hline \multirow{2}{*}{$\begin{array}{l}\text { Hypot } \\
\text { hesis }\end{array}$} & \multirow{2}{*}{ Path } & \multicolumn{2}{|c|}{ Actual Users } & \multicolumn{2}{|c|}{ Potential Users } & \multirow{2}{*}{$\begin{array}{c}\begin{array}{c}\text { Multi- } \\
\text { Group }\end{array} \\
\text { Analysis } \\
\begin{array}{c}\text { p-Value } \\
\text { new }\end{array}\end{array}$} \\
\hline & & $\begin{array}{c}\text { Path } \\
\text { Coeffici } \\
\text { ents } \\
\end{array}$ & $\begin{array}{c}\text { t- } \\
\text { Value }\end{array}$ & $\begin{array}{c}\text { Path } \\
\text { Coefficient } \\
\text { s } \\
\end{array}$ & $\begin{array}{c}\text { t- } \\
\text { Value }\end{array}$ & \\
\hline $\mathrm{H}_{1}$ & $\begin{array}{l}\text { Performance Expectancy } \rightarrow \text { Behavioral } \\
\text { Intention }\end{array}$ & 0.020 & 0.228 & 0.135 & 1.480 & 0.361 \\
\hline $\mathrm{H}_{2 \mathrm{a}}$ & Effort Expectancy $\rightarrow$ Behavioral Intention & 0.067 & 0.573 & -0.170 & 2.584 & 0.083 \\
\hline $\mathrm{H}_{2 \mathrm{~b}}$ & Effort Expectancy $\rightarrow$ Performance Expectancy & 0.833 & $\begin{array}{c}25.064 \\
*\end{array}$ & 0.509 & $5.940^{*}$ & $0.000^{*}$ \\
\hline $\mathrm{H}_{3}$ & Social Influence $\rightarrow$ Behavioral Intention & -0.037 & 0.484 & 0.239 & $2.851 *$ & $0.013 *$ \\
\hline $\mathrm{H}_{4 \mathrm{a}}$ & $\begin{array}{l}\text { Perceived Religiosity Obligation } \rightarrow \text { Behavioral } \\
\text { Intention }\end{array}$ & 0.209 & $2.732 *$ & 0.189 & $2.183^{*}$ & 0.865 \\
\hline $\mathrm{H}_{4 \mathrm{~b}}$ & $\begin{array}{l}\text { Perceived Religiosity Obligation } \rightarrow \text { Performance } \\
\text { Expectancy }\end{array}$ & 0.040 & 0.912 & 0.270 & $4.028^{*}$ & $0.004 *$ \\
\hline $\mathrm{H}_{5}$ & Compatibility $\rightarrow$ Behavioral Intention & 0.352 & $4.086^{*}$ & 0.364 & $4.131 *$ & 0.905 \\
\hline $\mathrm{H}_{6}$ & Perceived Trust $\rightarrow$ Behavioral Intention & 0.236 & $3.179 *$ & 0.149 & $1.735^{*}$ & 0.433 \\
\hline $\mathrm{H}_{7}$ & Perceived Risk $\rightarrow$ Behavioral Intention & -0.001 & 0.010 & 0.075 & 1.195 & 0.372 \\
\hline $\mathrm{H}_{8}$ & Perceived Cost $\rightarrow$ Behavioral Intention & 0.001 & 0.020 & -0.052 & 0.526 & 0.663 \\
\hline
\end{tabular}

The results of the multi-group analysis show significant differences in the effect of social influence on behavioral intention across both groups with a p-value of $0.013\left(\mathrm{H}_{3}\right)$. For impact on performance expectancy, both effort expectancy and the perceived influence of religiosity obligation have significant differences across the groups with p-values of 0.000 and $0.004\left(\mathrm{H}_{2 \mathrm{~b}}\right.$ and $\mathrm{H}_{4 \mathrm{~b}}$ ). Performance expectancy, effort expectancy, compatibility, perceived trust, perceived risk, and perceived cost do not show significant differences in the behavioral intention of Islamic mobile payment across both groups $\left(\mathrm{H}_{1}, \mathrm{H}_{2 \mathrm{a}}, \mathrm{H}_{4 a}, \mathrm{H}_{5}, \mathrm{H}_{6}, \mathrm{H}_{7}\right.$, and $\left.\mathrm{H}_{8}\right)$. These results confirm that $\mathrm{H}_{9}$ is supported.

\section{Discussion}

Performance expectancy has a positive effect on behavioral intention, which confirms and supports the results of previous studies (Gupta \& Arora, 2019; Rahi et al., 2019; Zhang et al., 2012). The study also shows that effort expectancy has a significant positive effect on the behavioral intention of Islamic mobile payments. This result aligns with previous studies that show the positive impact 
of effort expectancy on behavioral intention (Alalwan, 2018; Gupta \& Arora, 2019; Rahi et al., 2019).

Effort expectancy has a significant positive effect on performance expectancy. This result was shown both in actual users and in those in the potential users group. These results were consistent with the results of previous studies on mobile payment (Liu et al., 2019; Oliveira et al., 2016; Rahi et al., 2019)). This result indicates that ease of use will influence consumer expectations of the benefits of a system. Ease of use will give the impression that reliable systems and technology support the services that are being provided. Thus, consumers will expect more benefits from Islamic mobile payment.

Social influence has a significant positive effect on the behavioral intention of Islamic mobile payment. The condition is similar to previous research, which describes the positive impact of social influence on behavioral intention (Hasan \& Gupta, 2020; Liu et al., 2019; Rahi et al., 2019). However, this condition does not occur in the actual user group where social influence does not positively influence behavioral intention. In the potential users, social influence has a significant positive effect on behavioral intention. Potential users are affected by their social environment because they have no experience using the Islamic mobile payment service. Consumers tend to rely on information from reference groups or opinion leaders to decide which service to use.

Perceived religiosity obligation has a positive effect on behavioral intention across the groups. These results confirm the results of previous research that discussed the impact of religiosity on the behavioral intention of Islamic banks (Bananuka et al., 2019), Islamic mobile banking (Suhartanto et al., 2019), and Islamic credit cards (Jamshidi \& Hussin, 2016). In making decisions concerning purchasing, consumers are influenced by the culture and norms, one of which is religion. The implementation of religious orders is one thing that consumers do every day, and it affects how consumers behave. Perceived religiosity obligation is related to consumers' trust that mobile payment services meet the Islamic aspect, and the effect is that consumers use the available Islamic mobile payment services.

Perceived religiosity obligation has a positive effect on performance expectancy. These results confirm previous research that discussed the impact of religiosity on perceived usefulness (Jamshidi \& Hussin, 2016; Suhartanto et al., 2019). Islamic mobile payments are expected to provide benefits for the consumer's transaction needs. This is because such payments both help with transaction needs and are perceived to have met the principles of Islamic finance. It leads to Islamic mobile payment being expected to provide additional benefits when compared to other mobile payments.

Compatibility has a positive effect on the behavioral intention of Islamic mobile payments. In the actual and potential users group, these results also showed that compatibility has a positive effect on behavioral intention concerning Islamic mobile payments. These results also confirm the results of previous research on mobile payments (Hasan \& Gupta, 2020; Oliveira et al., 2016; Phonthanukitithaworn et al., 2016), which states that compatibility has a positive effect on behavioral intention. The result shows that consumers will use a service if the service meets their needs. The suitability of services for consumers' needs increases the intention to use these services in daily transactions.

Perceived trust has a significant positive effect on the behavioral intention of Islamic mobile payments. These results confirm previous research that described that perceived trust positively affects behavioral intention (Alalwan, 2018; Liu et al., 2019; Patil et al., 2020). Actual users believe that Islamic mobile payments provide security for them, and this affects the intention to use the service. The result shows that actual users pay more attention to trust and security in mobile payment services than to providing personal information during transactions (Phonthanukitithaworn et al., 2016). Perceived trust has a significant positive effect on the actual users, but it has no significant impact on potential users. Potential users have enough confidence in similar services related to safeguarding personal information and data, so perceived trust does not affect their intention to use Islamic mobile payments.

Perceived risk does not have a significant negative effect on behavioral intention. This result is different from previous studies that have shown a significant negative impact of perceived 
risk on the behavioral intention of mobile payments for users and non-users (Abrahão et al., 2016; Liu et al., 2019; Tan \& Leby Lau, 2016). Other studies have shown that there is no significant negative effect of perceived risk on behavioral intention. The result shows that consumers believe that the technology and systems used in mobile payments are not too risky (Ozturk et al., 2017). Users' experience using mobile payments shows that the service can provide benefits that outweigh any possible risks, so that the potential risk is assessed as being low.

Perceived cost does not have a negative effect on behavioral intention. The result is different from the results of previous research in which it was stated that there is a significant negative impact of perceived cost on behavioral intention on mobile payments for both users and non-users. Potential users tend to have no experience, so they pay less attention to the transaction costs that occur and the possibility of additional costs (Phonthanukitithaworn et al., 2016). Most users have experience making conventional mobile payments. Islamic mobile payments are considered similar in terms of the imposition of service transaction fees, so they pay less attention to the transaction cost. Islamic mobile payments also are considered quite competitive in terms of costs, so this factor does not affect the intention to use the service.

The difference is in the positive effect of social influence on behavioral intention. Social impact has a significant positive effect on the behavioral intention for the potential users, but it is not significant for the actual users. In contrast, potential users tend to be influenced by reference groups and opinion leaders in making certain decisions, including service encounters that will be conducted (Abrahão et al., 2016; Moorthy et al., 2020; Tan \& Leby Lau, 2016). The Islamic users of mobile payments will rely more on their experience than on references from groups or opinion leaders because users have firsthand experience with the value offered by the service.

\section{Conclusion}

This study makes a theoretical contribution by developing the UTAUT theory using variables regarding compatibility, perceived trust, perceived risk, and perceived cost. Compatibility is shown to have a significant positive effect on behavioral intention. There is a difference between actual users and potential users concerning social influence, where these variables only affect potential users. Meanwhile, perceived trust is shown to have a significant effect on behavioral intentions only among actual users.

Consumers tend to use the service if the service is following their lifestyle and way of transacting. Service providers can use this insight to offer Islamic mobile payments by delivering the service according to how customers transact and provide other more varied services. It will help consumers understand that the features provided by mobile payments meet their personal transaction needs. When potential users know that the features offered are diverse and meet their various transaction needs, they will use Islamic mobile payments.

Potential users will base their decisions on reviews, suggestions from reference groups, or suggestions from opinion leaders. Thus, service providers should approach opinion leaders who are considered respected and who understand financial transactions and ask them to endorse Islamic mobile payments. The endorsement can be done through social media or by activating promotions in the area where the opinion leader gathers or talks to his reference group.

The more consumers who believe the service is safe and trustworthy, the greater the intention to use the service will be among other people. Thus, service providers should be aware of this and provide honest and caring services to consumers. The Islamic label will increase consumers' expectations of this. The duty of the service provider to maintain the services provided can confirm the trust of consumers. One example is by providing promotional information without including marketing tricks.

Limitations were encountered in this research that should be dealt with in future investigations. Most of the relationships between exogenous and endogenous variables are more directly related to behavioral intention. At the same time, many previous studies have supported the indirect relationship between these variables. Thus, it is suggested that future researchers explore the indirect effect between the variables examined in the current study. In addition, the perceived religiosity obligation has proven to be an influential variable. 


\section{Author Contributions}

Conceptualization: Exval Mahendra Saputro \& Sri Rahayu Hijrah Hati

Data curation: Exval Mahendra Saputro

Formal analysis: Exval Mahendra Saputro \& Sri Rahayu Hijrah Hati

Investigation: Exval Mahendra Saputro \& Sri Rahayu Hijrah Hati

Methodology: Exval Mahendra Saputro \& Sri Rahayu Hijrah Hati

Project administration: Exval Mahendra Saputro \& Sri Rahayu Hijrah Hati

Supervision: Sri Rahayu Hijrah Hati

Validation: Exval Mahendra Saputro \& Sri Rahayu Hijrah Hati

Visualization: Exval Mahendra Saputro

Writing - original draft: Exval Mahendra Saputro

Writing - review \& editing: Sri Rahayu Hijrah Hati

\section{References}

Abrahão, R. de S., Moriguchi, S. N., \& Andrade, D. F. (2016). Intention of adoption of mobile payment: An analysis in the light of the Unified Theory of Acceptance and Use of Technology (UTAUT). RAI Revista de Administração e Inovação, 13(3), 221-230. https://doi.org/10.1016/j.rai.2016.06.003

Alalwan, A. A. (2018). Examining adoption of mobile internet in Saudi Arabia_Extending TAM with perceived enjoyment, innovativeness and trust. Technology in Society, 55, 100-110. https://doi.org/10.1016/j.techsoc.2018.06.007

Amin, H., Rahim Abdul Rahman, A., Laison Sondoh, S., \& Magdalene Chooi Hwa, A. (2011). Determinants of customers' intention to use Islamic personal financing: The case of Malaysian Islamic banks. Journal of Islamic Accounting and Business Research, 2(1), 22-42. https://doi.org/10.1108/17590811111129490

Au, Y. A., \& Kauffman, R. J. (2008). The economics of mobile payments: Understanding stakeholder issues for an emerging financial technology application. Electronic Commerce Research and Applications, 7(2), 141-164. https://doi.org/10.1016/j.elerap.2006.12.004

Bananuka, J., Kasera, M., Najjemba, G. M., Musimenta, D., Ssekiziyivu, B., \& Kimuli, S. N. L. (2019). Attitude: Mediator of subjective norm, religiosity and intention to adopt Islamic banking. Journal of Islamic Marketing, 11(1), 81-96. https:// doi.org/10.1108/JIMA-02-20180025

Banjarnahor, D. (2021, April 16). Kado milad ke-1, pengguna link aja syariah tembus 2,5 juta. CNBC Indonesia. Retrieved from https:/ /www.cnbcindonesia.com/tech/2021041523472037-238291/kado-milad-ke-1-pengguna-linkaja-syariah-tembus-25-juta

Choi, H., Park, J., Kim, J., \& Jung, Y. (2020). Consumer preferences of attributes of mobile payment services in South Korea. Telematics and Informatics, 51, 1-15 https://doi.org/10.1016/j.tele.2020.101397

Davis, F. D. (1989). Perceived usefulness, perceived ease of use, and user acceptance of information technology. MIS Quarterly, 13(3), 319-339. https://doi.org/10.2307/249008

Davis, F. D., Bagozzi, R. P., \& Warshaw, P. R. (1989). User acceptance of computer technology: A comparison of two theoretical models. Management Science, 35(8), 982-1003. Retrieved from https://www.jstor.org/stable/2632151

De Luna, I. R., Montoro-Ríos, F., Liébana-Cabanillas, F., \& de Luna, J. G. (2017). NFC technology acceptance for mobile payments: A Brazilian perspective. Review of Business Management, 19(63), 82-103. https://doi.org/10.7819/rbgn. v0i0.2315 
Finstad, K. (2010). Response interpolation and scale sensitivity: Evidence against 5-point scales. Journal of Usability Studies, 5(3), 104-110. Retrieved from https://uxpajournal.org/responseinterpolation-and-scale-sensitivity-evidence-against-5-point-scales/

Gefen, Karahanna, \& Straub. (2003). Trust and TAM in online shopping: An integrated model. MIS Quarterly, 27(1), 51-90. https://doi.org/10.2307/30036519

Gupta, K., \& Arora, N. (2019). Investigating consumer intention to accept mobile payment systems through unified theory of acceptance model: An Indian perspective. South Asian Journal of Business Studies, 9(1), 88-114. https://doi.org/10.1108/SAJBS-03-2019-0037

Hair, Ringle, C. M., \& Sarstedt, M. (2011). PLS-SEM: Indeed a Silver Bullet. Journal of Marketing Theory and Practice, 19(2), 139-152. https://doi.org/10.2753/MTP1069-6679190202

Handarkho, Y. D., Harjoseputro, Y., Samodra, J. E., \& Irianto, A. B. P. (2021). Understanding proximity mobile payment continuance usage in Indonesia from a habit perspective. Journal of Asia Business Studies, 15(3), 420-440. https://doi.org/10.1108/JABS-02-2020-0046

Hasan, A., \& Gupta, S. K. (2020). Exploring tourists' behavioural intentions towards use of select mobile wallets for digital payments. Paradigm, 24(2), 177-194. https://doi.org/10.1177/0971890720959519

Iman, N. (2018). Is mobile payment still relevant in the fintech era? Electronic Commerce Research and Applications, 30, 72-82. https://doi.org/10.1016/j.elerap.2018.05.009

Jaffar, M. A., \& Musa, R. (2014). Determinants of attitude towards islamic financing among halalcertified micro and smes: A preliminary investigation. Procedia - Social and Behavioral Sciences, 130, 135-144. https://doi.org/10.1016/j.sbspro.2014.04.017

Jamshidi, D., \& Hussin, N. (2016). Forecasting patronage factors of Islamic credit card as a new ecommerce banking service: An integration of TAM with perceived religiosity and trust. Journal of Islamic Marketing, 7(4), 378-404. https:/ /doi.org/10.1108/JIMA-07-2014-0050

Jatmiko, B.P. (2021, January 13). LinkAja catat pertumbuhan pengguna hingga 65 persen sepanjang 2020. KOMPAS. Retrieved from https://money.kompas.com/read/2021/01/13/114112826/linkaja-catat-pertumbuhanpengguna-hingga-65-persen-sepanjang-2020

Johan, Z. J., Hussain, M. Z., Mohd, R., \& Kamaruddin, B. H. (2020). Muslims and non-Muslims intention to hold Shariah-compliant credit cards: A SmartPLS approach. Journal of Islamic Marketing. https://doi.org/10.1108/JIMA-12-2019-0270

KNEKS. (2019, April 1). Kebutuhan digital payment syariah sangat mendesak. Komite Nasional Ekonomi dan Keuangan Syariah. Retrieved from https://www.knks.go.id/isuutama/12/kebutuhan-digital-payment-syariah-sangatmendesak

KNEKS. (2020, April 17). Layanan Syariah LinkAja resmi diluncurkan. Komite Nasional Ekonomi dan Keuangan Syariah. Retrieved from https://knks.go.id/berita/234/layanan-syariahlinkaja-resmi-diluncurkan?category $=1$

Lewis, J. R. (1993). Multipoint scales: Mean and median differences and observed significance levels. International Journal of Human-Computer Interaction, 5(4), 383-392. https://doi.org/10.1080/10447319309526075

Liébana-Cabanillas, F., de Luna, I. R., \& Montoro-Ríos, F. (2017). Intention to use new mobile payment systems: A comparative analysis of SMS and NFC payments. Economic ResearchEkonomska Istrą̌ivanja, 30(1), 892-910. https://doi.org/10.1080/1331677X.2017.1305784 
Liébana-Cabanillas, F., Sánchez-Fernández, J., \& Muñoz-Leiva, F. (2014). The moderating effect of experience in the adoption of mobile payment tools in virtual social networks: The MPayment Acceptance Model in Virtual Social Networks (MPAM-VSN). International Journal of Information Management, 34(2), 151-166. https://doi.org/10.1016/j.ijinfomgt.2013.12.006

Lin, W. R., Lin, C.-Y., \& Ding, Y.-H. (2020). Factors affecting the behavioral intention to adopt mobile payment: An empirical study in Taiwan. Mathematics, 8(10), 1851. https://doi.org/10.3390/math8101851

Linkaja. (2020, April 14). LinkAja luncurkan layanan Syariah pertama di Indonesia. Linkaja. Retrieved from https://www.linkaja.id

Liputan6. (2021, January 30). Bank Syariah Mandiri catatkan laba bersih rp 1,43 triliun di 2020. Liputan6. Retrieved from https://www.liputan6.com/bisnis/read/4470957/bank-syariahmandiri-catatkan-laba-bersih-rp-143-triliun-di-2020

Liu, Z., Ben, S., \& Zhang, R. (2019). Factors affecting consumers' mobile payment behavior: A meta-analysis. Electronic Commerce Research, 19, 575-601. https://doi.org/doi.org/10.1007/s10660-019-09349-4

Luarn, P., \& Lin, H. H. (2005). Toward an understanding of the behavioral intention to use mobile banking. Computers in Human Behavior, 21(6), 873-891. https://doi.org/10.1016/j.chb.2004.03.003

Mayer, R. C., Davis, J. H., \& Schoorman, F. D. (1995). An integrative model of organizational trust. The Academy of Management Review, 20(3), 709-734. https://doi.org/10.2307/258792

Moorthy, K., Chun T’ing, L., Chea Yee, K., Wen Huey, A., Joe In, L., Chyi Feng, P., \& Jia Yi, T. (2020). What drives the adoption of mobile payment? A Malaysian perspective. International Journal of Finance \& Economics, 25(3), 349-364. https://doi.org/10.1002/ijfe.1756

Mouakket, S. (2020). Investigating the role of mobile payment quality characteristics in the United Arab Emirates: Implications for emerging economies. International Journal of Bank Marketing, 38(7), 1465-1490. https://doi.org/10.1108/IJBM-03-2020-0139

MUI. (2018, July 23). Ini fatwa terbaru DSN-MUI tentang uang elektronik dan layanan pembiayaan berbasis IT. Majelis Ulama Indonesia. Retrieved from https://mui.or.id/berita/11352/inifatwa-terbaru-dsn-mui-tentang-uang-elektronik-dan-layanan-pembiayaan-berbasis-it/

Oliveira, T., Thomas, M., Baptista, G., \& Campos, F. (2016). Mobile payment: Understanding the determinants of customer adoption and intention to recommend the technology. Computers in Human Behavior, 61, 404-414. https://doi.org/10.1016/j.chb.2016.03.030

Ozturk, A. B., Bilgihan, A., Salehi-Esfahani, S., \& Hua, N. (2017). Understanding the mobile payment technology acceptance based on valence theory: A case of restaurant transactions. International Journal of Contemporary Hospitality Management, 29(8), 2027-2049. https://doi.org/10.1108/IJCHM-04-2016-0192

Patil, P., Tamilmani, K., Rana, N. P., \& Raghavan, V. (2020). Understanding consumer adoption of mobile payment in India: Extending Meta-UTAUT model with personal innovativeness, anxiety, trust, and grievance redressal. International Journal of Information Management, 54, 102144. https://doi.org/10.1016/j.ijinfomgt.2020.102144

Pavlou, P. A. (2003). Consumer acceptance of electronic commerce: integrating trust and risk with the technology acceptance model. International Journal of Electronic Commerce, 7(3), 101-134. https://doi.org/10.1080/10864415.2003.11044275 
Phonthanukitithaworn, C., Sellitto, C., \& Fong, M. W. L. (2016). A comparative study of current and potential users of mobile payment services. SAGE Open, 6(4), 215824401667539. https://doi.org/10.1177/2158244016675397

Prayoga, F. (2020, December 15). Potensi ekonomi syariah indonesia luar biasa, begini faktanya, Okezone. Retrieved from https://www.okezone.com/. https://www.okezone.com/tren/read/2020/12/15/620/2327880/potensi-ekonomisyariah-indonesia-luar-biasa-begini-faktanya

Putri, A. F., Handayani, P. W., \& Shihab, M. R. (2020). Environment factors affecting individual's continuance usage of mobile payment technology in Indonesia. Cogent Engineering, 7(1), 1846832. https://doi.org/10.1080/23311916.2020.1846832

Rahi, S., Othman Mansour, M. M., Alghizzawi, M., \& Alnaser, F. M. (2019). Integration of UTAUT model in internet banking adoption context: The mediating role of performance expectancy and effort expectancy. Journal of Research in Interactive Marketing, 13(3), 411-435. https://doi.org/10.1108/JRIM-02-2018-0032

Ramdhani, A., Alamanda, D. T., Harisana, M. H., \& Akbar, G. G. (2020). The factors that determine interest to use of mobile payment: Study on the Students of Garut University, Indonesia. The Asian Journal of Technology Management (AJTM), 13(3), 257-265. https://doi.org/10.12695/ajtm.2020.13.3.6

Rogers, E. M. (2003). Diffusion of innovations (Fifth). Free Press.

Schierz, P. G., Schilke, O., \& Wirtz, B. W. (2010). Understanding consumer acceptance of mobile payment services: An empirical analysis. Electronic Commerce Research and Applications, 9, 209216. https://doi.org/doi:10.1016/j.elerap.2009.07.005

Sobti, N. (2019). Impact of demonetization on diffusion of mobile payment service in India: Antecedents of behavioral intention and adoption using extended UTAUT model. Journal of Advances in Management Research, 16(4), 472-497. https://doi.org/10.1108/JAMR-092018-0086

Suhartadi, I. (2020, February 26). RI berpotensi jadi pemain utama di industri keuangan syariah dunia. Investor. Retrieved from https://investor.id/finance/ri-berpotensi-jadi-pemainutama-di-industri-keuangan-syariah-dunia

Suhartanto, D., Dean, D., Ismail, T. A. T., \& Sundari, R. (2019). Mobile banking adoption in Islamic banks: Integrating TAM model and religiosity-intention model. Journal of Islamic Marketing, 11(6), 1405-1418. https://doi.org/10.1108/JIMA-05-2019-0096

Tan, E., \& Leby Lau, J. (2016). Behavioural intention to adopt mobile banking among the millennial generation. Young Consumers, 17(1), 18-31. https://doi.org/10.1108/YC-07-2015-00537

Tang, G., \& Li, D. (2015). Is there a relation between religiosity and customer loyalty in the Chinese context? International Journal of Consumer Studies, 39(6), 639-647. https://doi.org/10.1111/ijcs.12197

Venkatesh, V., Morris, M. G., Davis, G. B., \& Davis, F. D. (2003). User acceptance of information technology: Toward a unified view. MIS Quarterly, 27(3), 425-478. https://doi.org/10.2307/30036540

Venkatesh, V., Thong, J. Y. L., \& Xu, X. (2012). Consumer acceptance and use of information technology: extending the unified theory of acceptance and use of technology. MIS Quarterly, 36(1), 157-178. https://doi.org/10.2307/41410412 
Walfajri, M. (2020, December 7). Bank Syariah Mandiri optimistis target transaksi QRIS di akhir 2020 tercapai. Kontan. Retrieved from https://newssetup.kontan.co.id/news/bank-syariahmandiri-optimistis-target-transaksi-qris-di-akhir-2020-tercapai

Wu, \& Wang. (2005). What drives mobile commerce? Information \& Management, 42(5), 719-729. https://doi.org/10.1016/j.im.2004.07.001

Zhang, L., Zhu, J., \& Liu, Q. (2012). A meta-analysis of mobile commerce adoption and the moderating effect of culture. Computers in Human Behavior, 28(5), 1902-1911. https://doi.org/10.1016/j.chb.2012.05.008

Zhou, T. (2011). The effect of initial trust on user adoption of mobile payment. Information Development, 27(4), 290-300. https://doi.org/10.1177/0266666911424075 


\section{Appendixes}

\section{Appendix 1. Summary of Operational Variables}

\begin{tabular}{|c|c|}
\hline Variables & Indicators \\
\hline $\begin{array}{l}\text { Performance } \\
\text { expectancy } \\
\text { (Abrahão et al., } \\
\text { 2016) }\end{array}$ & $\begin{array}{l}\text { PE1 - Islamic mobile payment would be a useful service in my daily activities. } \\
\text { PE2 - Islamic mobile payment would perform financial transactions more quickly. } \\
\text { PE3 - Islamic mobile payment would save time, so I can do other daily activities. } \\
\text { PE4 - Islamic mobile payment would bring greater convenience. }\end{array}$ \\
\hline $\begin{array}{l}\text { Effort } \\
\text { expectancy } \\
\text { (Abrahão et al., } \\
\text { 2016) }\end{array}$ & $\begin{array}{l}\text { EE1 - My interaction with the Islamic mobile payment service would be clear and easy to } \\
\text { understand. } \\
\text { EE2 - It would be easy for me to develop the skills to use Islamic mobile payment services. } \\
\text { EE3 - I believe that it is easy to use Islamic mobile payment. } \\
\text { EE4 - Learning to use the Islamic mobile payment system would be easy for me. }\end{array}$ \\
\hline $\begin{array}{l}\text { Social influence } \\
\text { (Abrahão et al., } \\
\text { 2016) }\end{array}$ & $\begin{array}{l}\text { SI1 - People who influence my behavior would think I should use Islamic mobile payment. } \\
\text { SI }- \text { People who are important to me would think that I should use Islamic mobile payment. } \\
\text { SI3 - People who are important to me could assist me in the use of Islamic mobile payment. } \\
\text { SI4 - In the future, organizations that offer Islamic mobile payment services will guarantee its } \\
\text { proper functioning. }\end{array}$ \\
\hline $\begin{array}{l}\text { Perceived } \\
\text { religiosity } \\
\text { obligation } \\
\text { (Amin et al., } \\
\text { 2011; Jamshidi } \\
\text { \& Hussin, 2016) }\end{array}$ & $\begin{array}{l}\text { PRO1 - Islamic mobile payment is in line with Islamic philosophy on financial transactions. } \\
\text { PRO2 - Islamic mobile payment is based on the Islamic principle of financial implementation. } \\
\text { PRO3 - Islamic mobile payment is free from riba'. } \\
\text { PRO4 - Islamic mobile payment is free from fraud. }\end{array}$ \\
\hline $\begin{array}{l}\text { Compatibility } \\
\text { (Phonthanukitith } \\
\text { aworn et al., } \\
\text { 2016) }\end{array}$ & $\begin{array}{l}\text { COM1 - Using Islamic mobile payment will fit well with my lifestyle. } \\
\text { COM2 - Using Islamic mobile payment will fit well with the way I like to conduct my payment } \\
\text { transactions. } \\
\text { COM3 - Using Islamic mobile payment will be completely compatible with my current } \\
\text { situation. }\end{array}$ \\
\hline $\begin{array}{l}\text { Perceived trust } \\
\text { (Jamshidi \& } \\
\text { Hussin, 2016; } \\
\text { Phonthanukitith } \\
\text { aworn et al., } \\
\text { 2016) }\end{array}$ & $\begin{array}{l}\text { PT1 - I believe that Islamic mobile payment parties are honest } \\
\text { PT2 - I believe that Islamic mobile payment offers a secure mobile payment service } \\
\text { PT3 - I believe that Islamic mobile payment will not take advantage of me. } \\
\text { PT4 - I believe that Islamic mobile payment cares about its customers. } \\
\text { PT5 - I believe that Islamic mobile payment is trustworthy. }\end{array}$ \\
\hline $\begin{array}{l}\text { Perceived risk } \\
\text { (Abrahão et al., } \\
\text { 2016) }\end{array}$ & $\begin{array}{l}\text { 1. I would not feel completely safe by providing personal information through an Islamic } \\
\text { mobile payment system } \\
\text { 2. I am worried about the future use of Islamic mobile payment services because other people } \\
\text { might access my data. } \\
\text { 3. I do not feel protected when sending confidential information via an Islamic mobile payment } \\
\text { system. } \\
\text { 4. The likelihood that something wrong will happen with Islamic mobile payment systems is } \\
\text { high. }\end{array}$ \\
\hline $\begin{array}{l}\text { Perceived cost } \\
\text { (Abrahão et al., } \\
\text { 2016) }\end{array}$ & $\begin{array}{l}\text { PC1 - I believe Islamic mobile payment services would be expensive. } \\
\text { PC2 - I would have financial barriers to use Islamic mobile payment services. } \\
\text { PC3 - I believe I would have to make a lot of effort to obtain the information that would make } \\
\text { me feel comfortable adopting Islamic mobile payment. } \\
\text { PC4 - It takes time to go through the process of moving to a new means of payment. }\end{array}$ \\
\hline $\begin{array}{l}\text { Behavioral } \\
\text { intention } \\
\text { (Venkatesh } \\
\text { 2003) }\end{array}$ & $\begin{array}{l}\text { BI1 - I intend to use Islamic mobile payment in the future. } \\
\text { BI2 - I plan to use Islamic mobile payment in the future. } \\
\text { BI3 - I predict I will use Islamic mobile payment in the future. }\end{array}$ \\
\hline
\end{tabular}

